\title{
Aerosol black carbon characteristics over a high-altitude Western Ghats location in Southern India
}

\author{
C. Udayasoorian ${ }^{1}$, R. M. Jayabalakrishnan ${ }^{2}$, A. R. Suguna ${ }^{2}$, Mukunda M. Gogoi ${ }^{3}$, and S. Suresh Babu ${ }^{3}$ \\ ${ }^{1}$ Department of Soil Science and Agricultural Chemistry, AC\&RI, Tamil Nadu Agricultural University, Killikulam, \\ Vallanad - 628 252, Tamil Nadu, India \\ ${ }^{2}$ Horticultural Research Station, Tamil Nadu Agricultural University, Vijayanagaram, Ooty - 643 001, Tamil Nadu, India \\ ${ }^{3}$ Space Physics Laboratory, Vikram Sarabhai Space Centre, Trivandrum-695022, Kerala, India
}

Correspondence to: C. Udayasoorian (cusoorian@yahoo.com)

Received: 1 July 2013 - Revised: 8 August 2014 - Accepted: 15 September 2014 - Published: 31 October 2014

\begin{abstract}
Aerosol black carbon (BC) mass concentrations were continuously monitored over a period of 2 years (April 2010 to May 2012) from a high-altitude location Ooty in the Nilgiris Mountain range in southern India to characterize the distinct nature of absorbing aerosols and their seasonality. Despite being remote and sparsely inhabited, BC concentrations showed significant seasonality with higher values $\left(\sim 0.96 \pm 0.35 \mu \mathrm{g} \mathrm{m}^{-3}\right)$ in summer (March to May), attributed to increased vertical transport of effluents in the upwind valley regions, which might have been confined to the surrounding valley regions within the very shallow winter boundary layer. The local atmospheric boundary layer (ABL) influence in summer was further modulated by the long-range transported aerosols from the eastern locations of Ooty. During monsoon (June-August), the concentrations were far reduced $\left(\sim 0.23 \pm 0.06 \mu \mathrm{g} \mathrm{m}^{-3}\right)$ due to intense precipitation. Diurnal variations were found conspicuous mainly during summer season associated with local ABL. The spectral absorption coefficients $\left(\alpha_{\text {abs }}\right)$ depicted, in general, flatter distribution (mostly $<1.0$ for more than $85 \%$ of daily mean values), suggesting the relative dominance of fossil fuel combustion, though showed marginal seasonal change with higher values of $\alpha_{\mathrm{abs}}$ in summer.
\end{abstract}

Keywords. Atmospheric composition and structure (aerosols and particles)

\section{Introduction}

Aerosol black carbon (BC), produced mainly due to incomplete combustion of fossil fuel or biomass, is amongst the strongest contributors to the radiative warming of the atmosphere (Marinoni et al., 2010), through its strong absorption over a wide wavelength range (from UV to IR). They can heat the air, alter atmosphere stability, large-scale circulations and cloud albedo by changing the hygroscopicity of cloud condensation nuclei. BC aerosols are inert in nature as a result of predominant sub-micron size and chemical structure. Being in the fine size range (median diameters in the range $100-200 \mathrm{~nm}$ ), they bear a long atmospheric residence time, thereby leading to deterioration of air quality and health hazards as easily respirable (Janssen et al., 2012). In addition, BC-containing particles are also associated with adverse effects such as crop yields, contaminating building materials and adversely impact terrestrial and aquatic ecosystems (Cao et al., 2009).

During recent years, $\mathrm{BC}$ has attracted special attention mainly because of its contribution to radiative warming of the atmosphere (Haywood and Shine, 1997; Myhre et al., 1998; Jacobson, 2001, 2002). The Intergovernmental Panel on Climate Change (IPCC, 2007) has estimated that the global mean clear-sky radiative forcing of $\mathrm{BC}$ is 0.23 $( \pm 0.25) \mathrm{W} \mathrm{m}^{-2}$, which is approximately half the value of methane, the second most important greenhouse gas after carbon dioxide. The developing world, especially the Asian region with its large population, rapidly growing industrialization and diverse living habitats, is believed to be one of the hotspots of carbonaceous aerosols (Oshima et al., 2012; IPCC, 2007). However, large gap areas still exists 
geographically. In this context, characterization of aerosol $\mathrm{BC}$ over different geographic locations of India assumes importance. It has been reported that biomass burning and fossil fuel combustion contribute $\sim 49 \%$ of the total fine mode aerosol burden over the Indian sub-continent (Gabriel et al., 2002), making the characterization of $\mathrm{BC}$ aerosols more important over distinct geographic locations of the country.

In view of the above, continuous measurement of aerosol $\mathrm{BC}$ was initiated from Ooty, a high-altitude location in Western Ghats of southern India in the Nilgiris Mountain range, to understand the aerosol absorption properties over this remote environment, and the changes in the spectral absorption associated with the changes in dominant source types with subdued human interference. The information of $\mathrm{BC}$ characteristics over this high-altitude location is also important in understanding the consequences of regional weather and climate implications. In this paper, we present the results of aerosol BC measurements carried out for the period from April 2010 to May 2012 to understand the absorption characteristics of $\mathrm{BC}$ at the high-altitude site.

\section{Experimental details}

\subsection{Site description}

The study area, Ooty $\left(11.4^{\circ} \mathrm{N}, 76.7^{\circ} \mathrm{E}, 2520 \mathrm{~m}\right.$ a.m.s.l.; Fig. 1), located in the district of the Nilgiris Mountain range in Indian state of Tamil Nadu, represents a fresh, clean and pleasant environment with highly subdued human activity. Dense forests, lofty mountains, extensive tea and coffee plantation and sprawling grasslands characterize the location. The Nilgiris Hills form a part of a larger chain of mountains known as the Western Ghats along the western side of India, which is one of the eight hottest hotspots of biological diversity in the world. As of 2011 India census, the Nilgiris district had population of 735394 , of which 88430 belonged to Ooty town.

\subsection{Instrumentation, database and analysis}

Continuous measurements of $\mathrm{BC}$ have been carried out from the ARFINET observatory, located at a distance of $\sim 8 \mathrm{~km}$ from the main town of Ooty using a seven-channel aethalometer (Model AE-31 of Magee Scientific, USA). Aethalometer is a field rugged instrument extensively used across the aerosol research community for continuous measurements of ambient BC mass concentration over a variety of environments (e.g. Hansen et al., 1984; Novakov et al., 2003; Moorthy et al., 2008; Babu et al., 2011a; Gogoi et al., 2014). The instrument measures attenuation of light beam at seven different wavelengths, namely $370,470,520,590$, 660,880 and $950 \mathrm{~nm}$, transmitted through the aerosols deposited continuously on a quartz fibre filter tape (Hansen et al., 1984). The difference in light transmission through the particle-laden sample spot and a particle-free reference

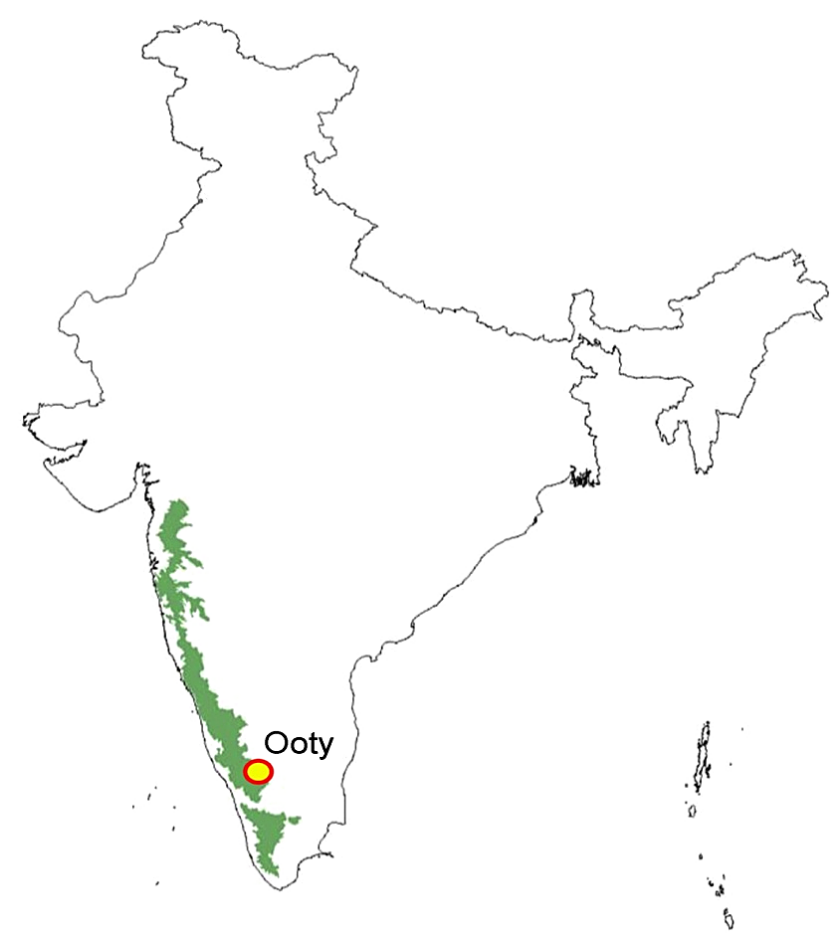

Figure 1. Geographical position of high-altitude location Ooty in Western Ghats of southern India in the Nilgiris Mountain range.

spot of the filter is used to compute the absorption coefficient, which is then converted into "equivalent BC mass" concentration using factory-set wavelength-dependent calibration factors (http://mageesci.com/Aethalometer). Observation at $880 \mathrm{~nm}$ wavelength is considered standard for BC measurement, as $\mathrm{BC}$ is the principal absorber of light at this wavelength, whereas other aerosol components have negligible absorption at this wavelength.

At Ooty, the aethalometer was operated under $50 \%$ maximum attenuation settings (to keep the loading at a low level), at a standard mass flow rate of $4 \mathrm{~L} \mathrm{~min}^{-1}$ and time base of $5 \mathrm{~min}$, on all the days and around the clock. However, it is important to note that the mass flow rate of $4 \mathrm{~L} \mathrm{~min}^{-1}$ is applicable under standard temperature $\left(T_{0} \sim 293 \mathrm{~K}\right)$ and pressure $\left(P_{0} \sim 1013 \mathrm{hPa}\right)$ conditions. As the ambient pressure at Ooty is lower than the standard conditions, the measured BC values were corrected (e.g. Moorthy et al., 2004) for its pressure. The true $\mathrm{BC}$ mass concentration $\left(M_{\mathrm{BC}}\right)$ is thus calculated as

$M_{\mathrm{BC}}=M_{\mathrm{BC}}^{*}\left[\frac{P_{0} T}{P T_{0}}\right]^{-1}$,

where $M_{\mathrm{BC}}^{*}$ is the instrument-measured raw mass concentration of $\mathrm{BC}$ at ambient conditions, $P_{0}$ and $P$ are the standard and ambient pressure and $T_{0}$ and $T$ are the corresponding temperatures. Details of the aethalometer principle, operation, uncertainties involved and error budget are reported in Weingartner et al. (2003), Arnott et al. (2005) and Nair et 
al. (2008). In general, the instrumental uncertainty of the aethalometer ranges from $50 \%$ at $0.05 \mu \mathrm{g} \mathrm{m}^{-3}$ to $6 \%$ at $1 \mu \mathrm{g} \mathrm{m}^{-3}$ (Corrigan et al., 2006).

Aerosol absorption coefficients $\left(\sigma_{\mathrm{abs}}\right)$ were estimated from the raw attenuation data of the aethalometer as a function of $\lambda$, for each set of measurements as

$\sigma_{\mathrm{abs}}(\lambda)=\frac{1}{C R} \cdot\left(\frac{\Delta \mathrm{ATN}(\lambda)}{\Delta t} \frac{A}{Q}\right)$,

where $A$ is the filter spot area, $Q$ the volumetric flow rate and $\triangle \operatorname{ATN}(\lambda)$ is the change in attenuation at the wavelength $\lambda$ due to particle load on the filter media during the time interval $\Delta t$. There are two major uncertainties in the estimation of $\sigma_{\text {abs }}$ due to the effect of multiple scattering in the filter papers and the shadowing effects by the collected aerosol particles (Weingartner et al., 2003; Arnott et al., 2005; Corrigan et al., 2006). The parameters $C$ and $R$ are correction factors for minimizing the inherent uncertainty associated with multiple scattering of light in the filter matrix and the change in the optical path length due to successive aerosol loadings. The correction for these uncertainties was done following Weingartner et al. (2003) incorporating values of $C=2.14$ and $R=1$.

The database collected using aethalometer for the period from April 2010 to May 2012 is used in the present study. Supplementary daily mean meteorological data were obtained from the Horticultural Research Station, Tamil Nadu Agricultural University, Ooty for representative meteorological information at the high-altitude western part of the country. The research station is located in the Nilgiris, the queen of hills at an altitude of $2240 \mathrm{~m}$ above mean sea level (a.s.l.), at nearly the same altitude of the measurement site (2520 m a.s.l.) at an aerial distance of about $1 \mathrm{~km}$ southwest.

\section{General meteorology}

The general meteorological conditions that prevailed over Ooty are characteristic of a subtropical highland climate. Despite its location in the tropics, Ooty generally features pleasant mild conditions throughout the year in sharp contrast to most parts of South India. However, night time is typically chilly in the months of January and February. The monthly mean values of temperatures are relatively consistent throughout the year; with average high temperatures ranging from about 17 to $20^{\circ} \mathrm{C}$ and average low temperatures lying between $5-12{ }^{\circ} \mathrm{C}$. The average precipitation is $1250 \mathrm{~mm}$ annually, with a markedly drier season from December through March. For the measurement period, the temporal variations of meteorological parameters (temperature, relative humidity and rainfall) are shown in Fig. 2, while that of wind speed and wind direction are shown in Fig. 3.

As can be seen from Fig. 2, the monthly temperature reached maximum value $\left(\sim 20-25^{\circ} \mathrm{C}\right)$ during the summer (March to May) and a minimum $\left(\sim 15-17^{\circ} \mathrm{C}\right)$ during

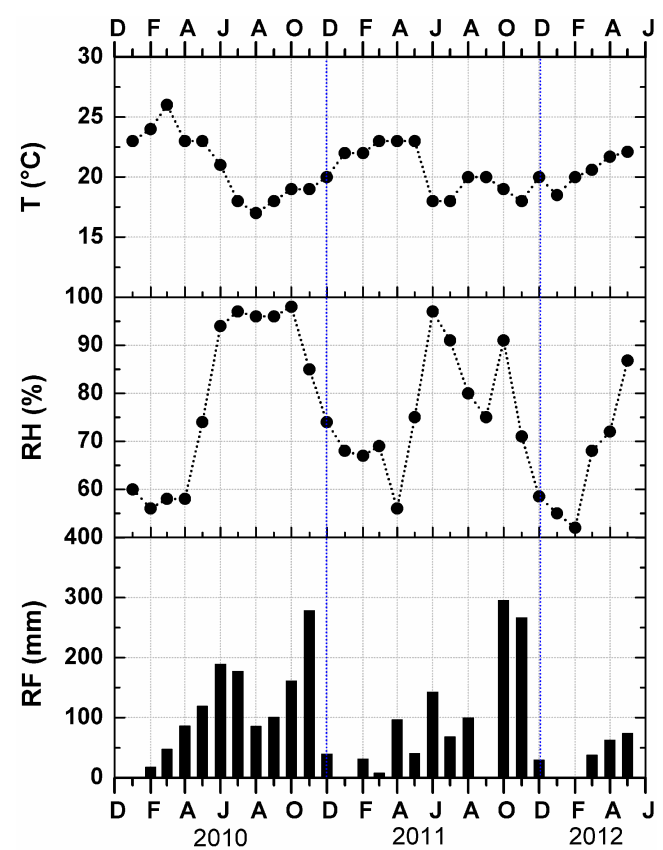

Figure 2. Temporal variation of monthly mean meteorological parameters: temperature $(T)$, relative humidity $(\mathrm{RH})$ and rainfall $(\mathrm{RF})$ at Ooty for the period from January 2010 to May 2012.

monsoon (June to August). The relative humidity was generally high $(>50 \%)$ throughout the period of observation. Seasonal rainfall was higher during monsoon and autumn (September and November) which accounted for $80 \%$ of total annual rainfall.

The winds however were highly seasonal, with low and moderate $\left(<4 \mathrm{~ms}^{-1}\right)$ northeasterlies/easterlies dominating the winter (December to February) and summer, changing over to westerlies in monsoon and autumn season as shown by the polar diagram in Fig. 3 .

\section{Results and discussions}

\subsection{Temporal variation of $\mathrm{BC}$ mass concentration}

The regular $\mathrm{BC}$ data at $5 \mathrm{~min}$ interval over the $2 \mathrm{yr}$ period is examined in Figs. 4 and 5 for the average temporal variations at diurnal and monthly timescales. It is seen that despite the large variation at shorter timescales (Fig. 4), the monthly variation (Fig. 5) has shown a consistent seasonality over the years with a conspicuous peak during summer (when the mean $\mathrm{BC}$ is $\sim 0.96 \pm 0.35 \mu \mathrm{g} \mathrm{m}^{-3}$ ) and low in monsoon (with a seasonal mean of $0.23 \pm 0.06 \mu \mathrm{g} \mathrm{m}^{-3}$ ), an annual amplitude (ratio of $\max / \min$ ) of $\sim 4$.

Diurnal variations of $\mathrm{BC}$ are very important in understanding the role of mesoscale atmospheric processes and the effect of local human activities. The diurnal variation of the atmospheric boundary layer (ABL) height and its structure is known to influence the surface BC concentrations (Moorthy 


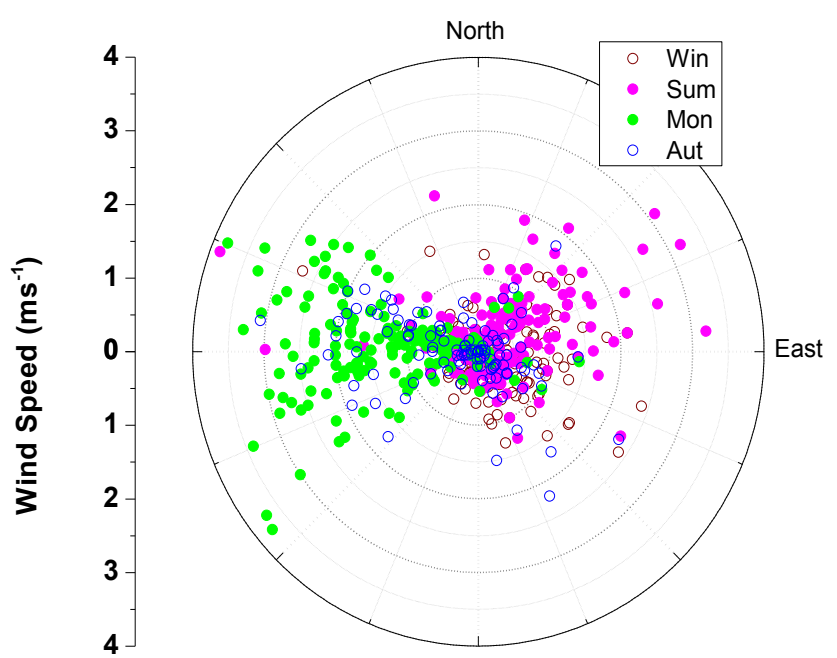

Figure 3. Daily mean values of wind speed and wind direction at Ooty during winter (maroon open circle), summer (pink solid circle), monsoon (green solid circle) and autumn (blue open circle) for the period from April 2010 to May 2012.

et al., 2003; Nair et al., 2007). The present study reveals (Fig. 4) a conspicuous evening peak (during 17:00 to 22:00 local time) in the diurnal variations of $\mathrm{BC}$ concentrations at the shorter timescales during February-May, and decrease gradually towards morning and become lowest during the early morning hours (05:00), again increases after the sunrise, typical to a continental site subjected to the dynamics of the atmospheric boundary layer (Nair et al., 2007; Balakrishnaiah et al., 2011). The diurnal variations remain inconspicuous from August to February, even though a less pronounced diurnal pattern similar to that in March-May is noticeable during June and October. Such behaviours suggest an important influence of the strong convective processes in flushing out valley-bound pollutants to the experimental location during summer leading to highest BC concentration. In addition, non-local transport, as well as buildup of aerosols associated with formation of stable layer in the evening might also be playing an important role. Variations of $\mathrm{BC}$ with meteorological variables at the site (air temperature, wind speed and direction) during the study period with different ambient conditions are discussed in a following section. With the advent of monsoon, diurnal variation is less pronounced as the much shallower boundary layer isolates the measurement site from the surrounding valley region. All these indicate that the diurnal variation of $\mathrm{BC}$ mass concentration at Ooty is similar to those seen over the continents, but at a much subdued strength because of the higher elevation and low thermal gradients of the location during a day.

Despite the large diurnal variation, the annual variation of monthly mean $\mathrm{BC}$ mass concentrations $\left(M_{\mathrm{BC}}\right)$ shown by the box and whisker plot in Fig. 5 depicts a systematic pattern, with the lowest value in July-September and highest during February-April. The solid circles are the monthly means and

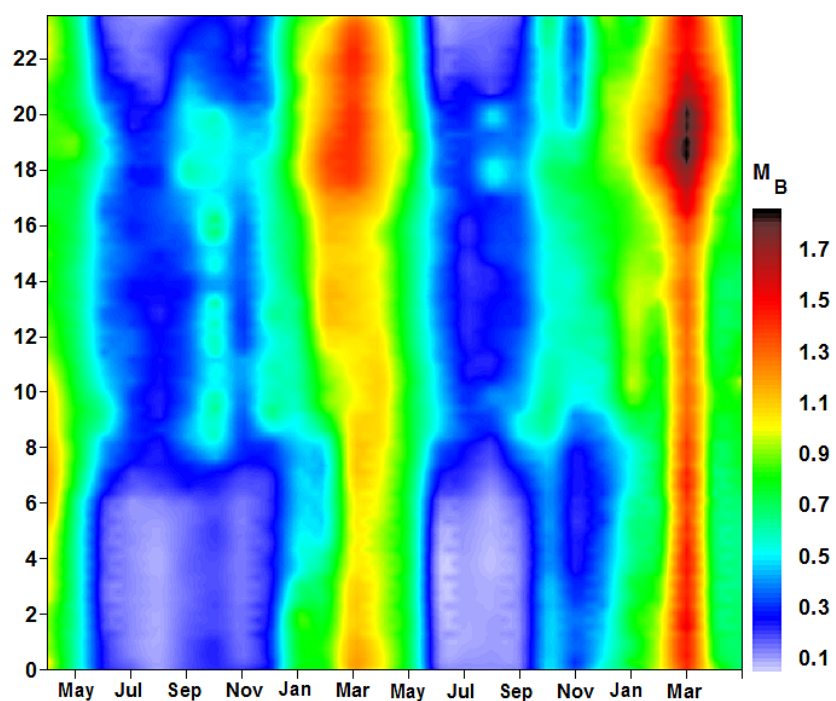

Figure 4. Diurnal variation (local time in hours along the $y$ axis) of $\mathrm{BC}$ at different months.

the whiskers show the standard deviations, while the boxes are used to represent 25 percentile (lower line), median (middle) and 75 percentile (top line) occurrences. The minimum and maximum values for the month are indicated by the open circles. During the study period, the least BC concentration of $0.2 \pm 0.08 \mu \mathrm{g} \mathrm{m}^{-3}$ occurred in July 2010, while the highest $\mathrm{BC}$ abundance of $1.47 \pm 0.16 \mu \mathrm{g} \mathrm{m}^{-3}$ was found in March 2012. The inter-annual variation of $M_{\mathrm{BC}}$ indicates that there is a significant enhancement in $\mathrm{BC}$ mass concentrations during March 2012 than those observed for the same period during 2011. The annual mean value of $\mathrm{BC}$ estimated from the entire data (irrespective of years) is $0.61 \pm 0.36 \mu \mathrm{g} \mathrm{m} \mathrm{m}^{-3}$. In all the above the numbers after the \pm symbol are the standard deviations. The seasonal mean values (in $\mu \mathrm{g} \mathrm{m}^{-3}$ ) of $\mathrm{BC}$ for the measurement period are $0.77 \pm 0.20,0.96 \pm 0.35$, $0.23 \pm 0.06$ and $0.35 \pm 0.09$ respectively for winter, summer, monsoon and autumn, being highest in summer (March to May) and lowest in monsoon.

The frequency distribution of daily mean $\mathrm{BC}$ at different seasons (solid line along the left $y$ axis in Fig. 6) is highly skewed. During summer, more than $90 \%$ of BC values remain above the annual mean $\left(0.61 \pm 0.36 \mu \mathrm{g} \mathrm{m}^{-3}\right)$, while most of the $\mathrm{BC}$ values remain below the annual mean during monsoon. The winter months shows a broad distribution of the occurrences of the $\mathrm{BC}$ values. The higher $\mathrm{BC}$ abundance during the summer is attributed to the increased vertical transport of effluents in the upwind valley regions (as already mentioned), which might have been confined to the surrounding valley regions within the very shallow winter boundary layer. The extended duration of daytime and abundant availability of solar radiation during February-May leads to turbulence and vertical mixing of BC. The local boundary layer influence is also enhanced further by the 


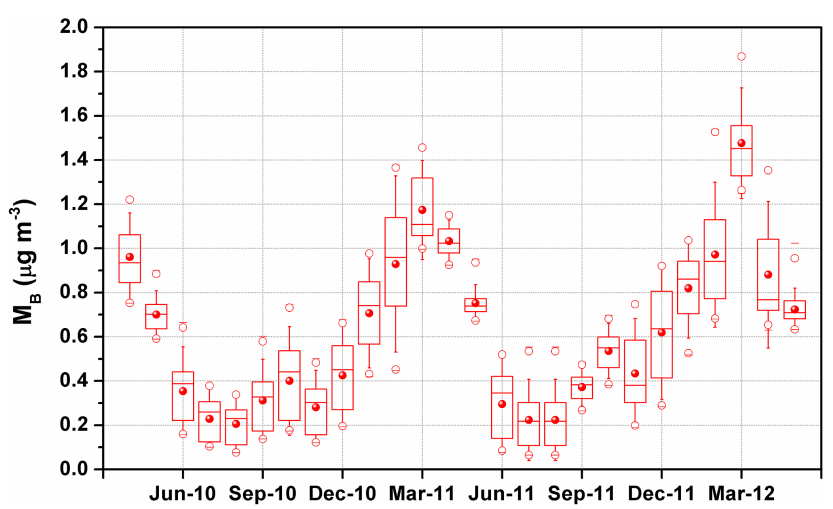

Figure 5. Temporal variations of monthly mean BC. The solid circles are the monthly means and whiskers show the standard deviations. The boxes represent occurrences of 25 percentile (lower line), median (middle) and 75 percentile (top line) $\mathrm{BC}$ values.

long range transported aerosols, contributing to the higher $\mathrm{BC}$ concentration in summer. During monsoon, as the temperature decreases to minimum, the convective activity becomes weak, and the ABL shallower. Thus the measurement site ( $\sim 200 \mathrm{~m}$ above the surrounding valley region) gets less influenced from the local and regional emissions, which by themselves are meagre. During autumn, the lower replenishment of aerosols after the monsoon washout, as well as the very reduced $A B L$ (due to low solar elevation), lead to a lower value of $\mathrm{BC}$, which gradually increases towards winter mainly due to the increase in local anthropogenic activities in the inhabited areas of Ooty town. With the advent of summer, the increased convection leads again to the deepening, and eventual break-up of the surface layer as the season advances, flushing up particles to be lofted and dispersed spatially by the prevailing winds. This leads to the peak BC concentration at the beginning of summer (e.g. March). However, as monsoon sets in the strong monsoon rain leads to depletion of $\mathrm{BC}$ concentration.

\subsection{Absorption properties}

The estimated monthly mean values of the absorption coefficient $\left(\sigma_{\mathrm{abs}}\right)$ at $550 \mathrm{~nm}$ varied between the highest value of $\sim 16.37 \pm 4.16 \mathrm{Mm}^{-1}$ in summer and the lowest value $\sim 4.20 \pm 0.99 \mathrm{Mm}^{-1}$ in monsoon. With a view to examining the contribution of distinct aerosol sources in changing the aerosol absorption properties at Ooty, the spectral variations of $\sigma_{\text {abs }}$ are examined, assuming a power law dependence of $\sigma_{\mathrm{abs}}$ with $\lambda$ of the form

$\sigma_{\mathrm{abs}}(\lambda)=\beta_{\mathrm{abs}} \lambda^{-\alpha_{\mathrm{abs}}}$,

where $\beta_{\mathrm{abs}}$ is a constant and $\alpha_{\mathrm{abs}}$ represent the absorption (Ångström) exponent. The spectral dependence of aerosol absorption coefficient $\left(\sigma_{\mathrm{abs}}\right)$ could be used to identify the presence of aerosol species, other than BC (such as OC and dust) that absorb strongly in the shorter-wavelength (blue
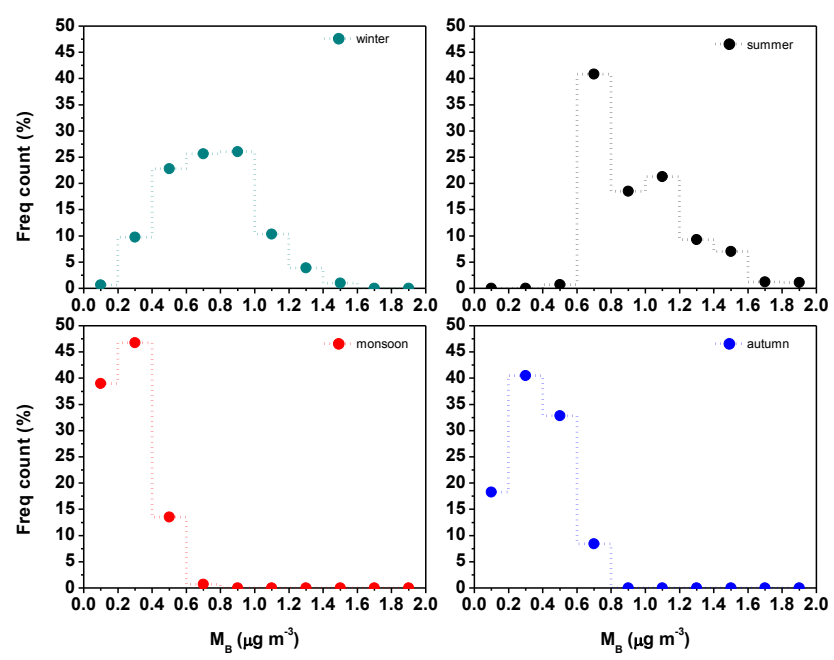

Figure 6. Frequency distribution of BC mass concentrations $\left(M_{\mathrm{B}}\right)$ in winter (December-February), summer (March-May), monsoon (June-August) and autumn (September-November) seasons.

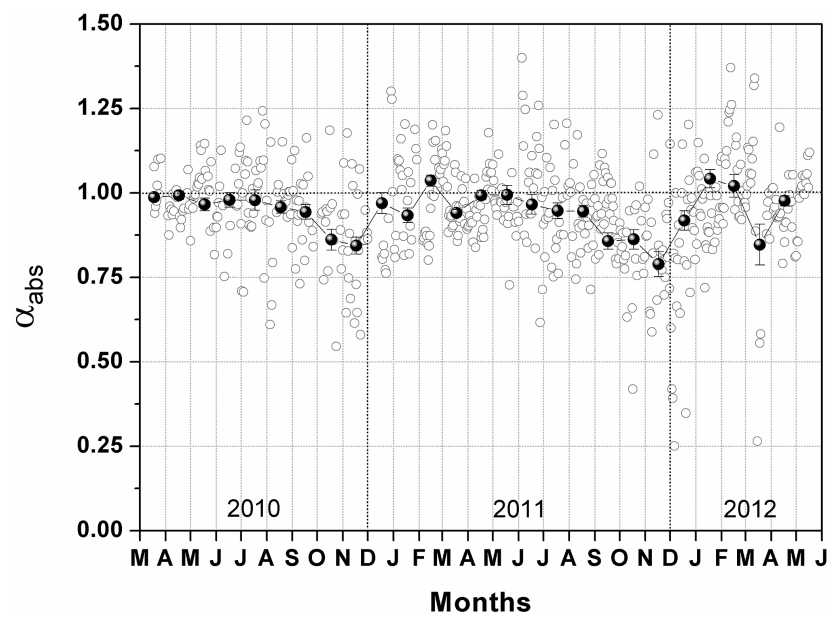

Figure 7. Temporal variation of spectral absorption coefficient $\left(\alpha_{\text {abs }}\right)$ for daily (open circles) and monthly (solid circles) mean values.

and ultraviolet) spectral regions (Kirchstetter et al., 2004). For BC (elemental) aerosols, originating from fossil fuel combustion, $\alpha$ assumes a value of $\sim 1.0$ (Kirchstetter et al., 2004). However, if the wavelength dependence of $\alpha_{\mathrm{abs}}$ significantly deviates from 1.0, it is indicative of the presence of the absorbing species such as dust or carbonaceous aerosols resulting from biomass burning or brown carbon, the spectral absorption of which increases more rapidly towards lower wavelengths. For example, for biomass smoke and dust aerosols, average values of $\alpha \approx 2$ have been reported (Kirchstetter et al., 2004; Bergstrom et al., 2007).

The monthly variation of $\alpha_{\text {abs }}$ superimposed with the daily mean values in Fig. 7 clearly indicates a seasonal change in $\alpha_{\text {abs }}$, with higher values during summer and decreasing 

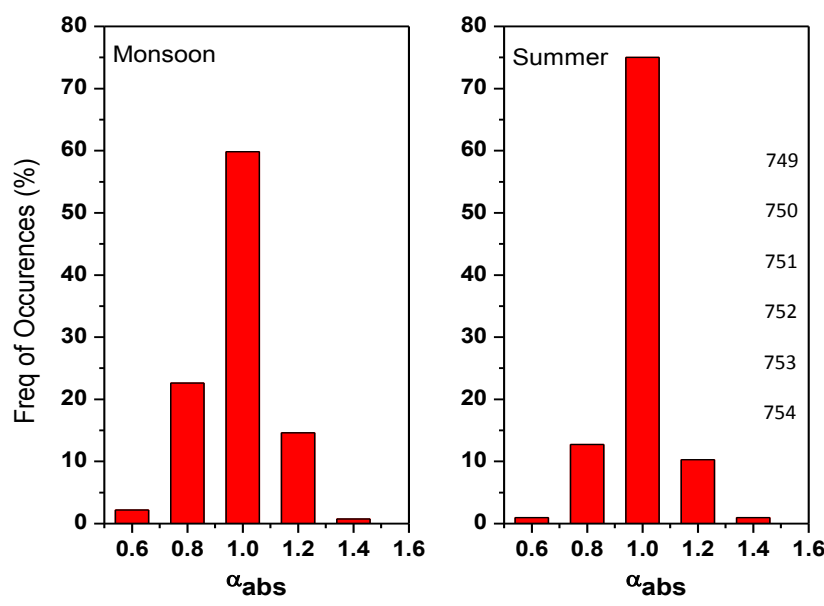

Figure 8. Frequency distribution of the daily mean values of $\alpha_{\mathrm{abs}}$ at two representative seasons of monsoon (June-August) and summer (March-May).

afterwards to winter season. However, it is interesting to note that the values of $\alpha_{\mathrm{abs}} \sim 1$ in most cases, and $>85 \%$ of the daily mean values remained $<1$. This clearly indicates the dominance of fossil fuel aerosols in modifying the aerosol absorption properties at Ooty. On the other hand, the lower values of $\alpha_{\text {abs }}(<1.0)$ during the monsoon season represent the typical background condition of the site with fossil fuel as the only source of spectral aerosol absorption. The frequency distribution of $\alpha_{\mathrm{abs}}$, as shown in Fig. 8 for two typical seasons of summer and monsoon, during which the $\mathrm{BC}$ concentration showed highest and lowest $\mathrm{BC}$ mass concentrations respectively, also showed no marginal change in the occurrences of the values of $\alpha_{\mathrm{abs}}$.

\section{MODIS fire count}

With a view to examining the distribution of potential biomass burning sources surrounding the experimental site and their role in modulating the spectral absorption properties of aerosols at Ooty, MODIS cloud-corrected fire pixels are shown in Fig. 9 for different seasons. The spatial distribution of fires in each season of summer, monsoon, autumn and winter (representing year 2011) in Fig. 9 clearly indicates that total area infested by forest fires and biomass burning is high winter and summer, compared to that during monsoon and autumn. This is well reflected in the monthly variation of $\alpha_{\text {abs }}$ (values increasing in winter and summer) in Fig. 7, showing a gradual increase in the relative dominance of biomass burning aerosols during winter and summer. However, wind patterns play a major role in advecting the biomass components, which are discussed below with respect to the local and synoptic conditions around the study region.

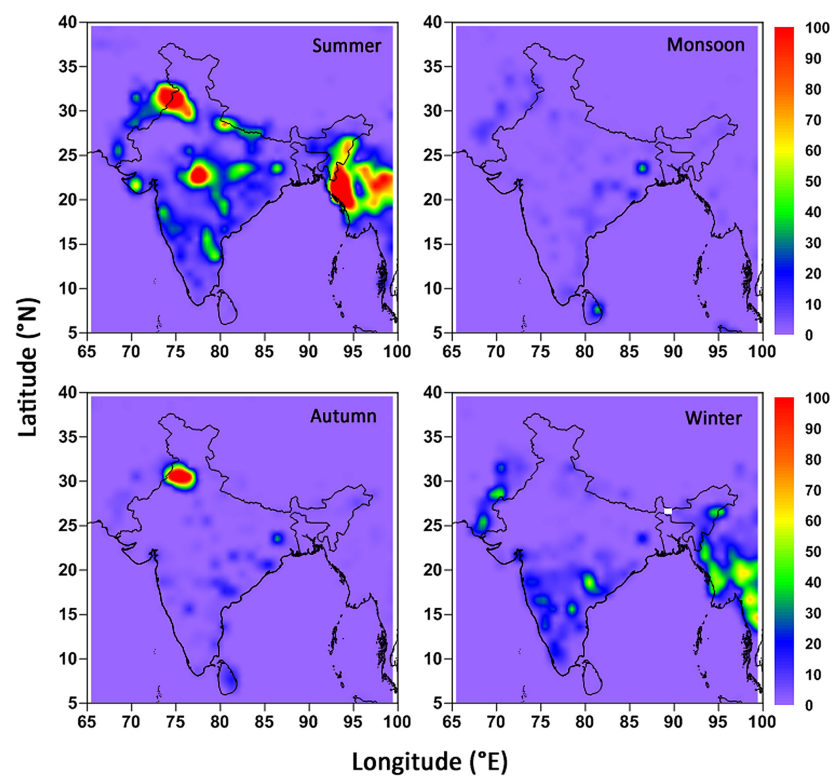

Figure 9. Spatial distribution of cloud-corrected MODIS fire pixel counts over the southern part of India during summer (March-May), monsoon (June-September), autumn (September-November) and winter (December-February) of 2011. Courtesy: Giovanni online visualization and analysis tools.

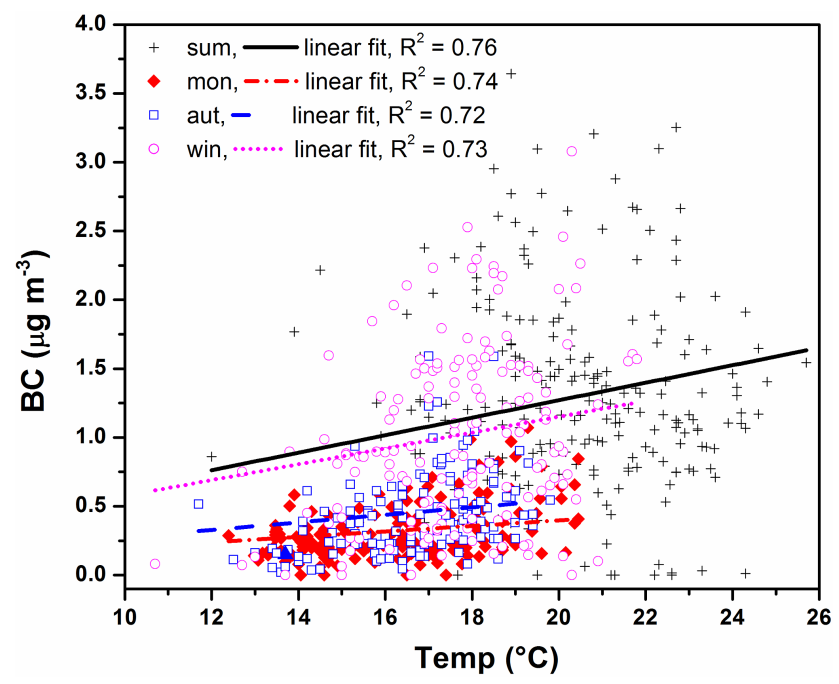

Figure 10. Variation of daily mean values of BC mass concentration with corresponding temperature at different seasons of summer (March-May), monsoon (June-August), autumn (SeptemberNovember) and winter (December-February).

\subsection{Variation of $\mathrm{BC}$ with meteorological parameters}

To understand the variation of $\mathrm{BC}$ with the local ambient conditions at different seasons, the daily mean values of $\mathrm{BC}$ are examined first with the variation of daily mean temperature with respect to different seasons as shown in Fig. 10. It can be seen from Fig. 10 that the association and slope 


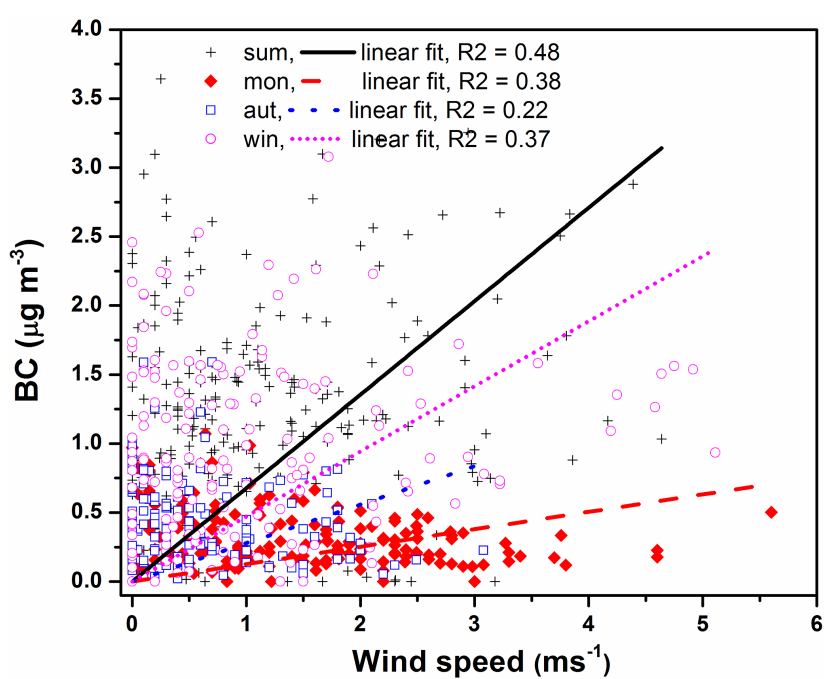

Figure 11. Variation of daily mean values of BC mass concentrations with corresponding wind speed at different seasons of summer (March-May), monsoon (June-August), autumn (SeptemberNovember) and winter (December-February).

of the variation of $\mathrm{BC}$ concentrations with temperatures are higher in summer months in comparison to the other seasons. Since the measurement location is a tourist place, maximum tourists visit Ooty during February to May. In addition, vehicular movement also increases during the peak summer season. Thus, increase in temperature during summer leads to higher dispersion of pollutants from the neighbouring town area and energize particles to reach the measurement site which is at a higher location from the surroundings.

Further, pollutant concentration is also dependent on the strength of the wind. In order to determine the effect of wind on $\mathrm{BC}$ concentrations, the variations of daily mean values of $\mathrm{BC}$ are examined with the variation of wind speed (Fig. 11) and direction (Fig. 12). Notwithstanding a fair amount of scatter, BC concentrations showed better correlation with increase in wind speed in summer. The increase in wind speed along with ambient temperature causes an increase in the ventilation coefficients, thereby dispersing the aerosols in the ambient air, and consequently causes them to reach the measurement site, which leads to the highest BC concentration during summer. With respect to wind direction in Fig. 12, large changes in $\mathrm{BC}$ concentration during summer were associated with northeasterlies and easterlies, when the winds were of continental origin (mainly during summer and winter) from the potential source region of combustion aerosols, while during monsoon, the large reductions in $\mathrm{BC}$ concentration were associated with the winds from westerly to northwesterly sectors, i.e. from the marine origin bringing cleaner air to the site.

The above discussion thus indicates the influence of local meteorological parameters (mainly temperature and wind) on the observed high concentration of $\mathrm{BC}$ at Ooty during summer seasons.

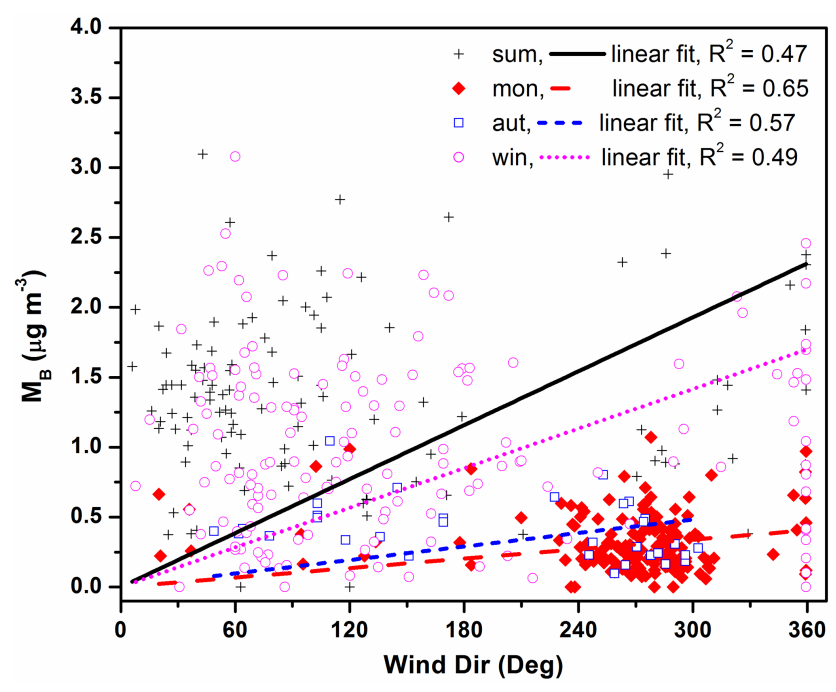

Figure 12. Variation of daily mean values of BC mass concentrations with corresponding wind direction at different seasons of summer (March-May), monsoon (June-August), autumn (SeptemberNovember) and winter (December-February).
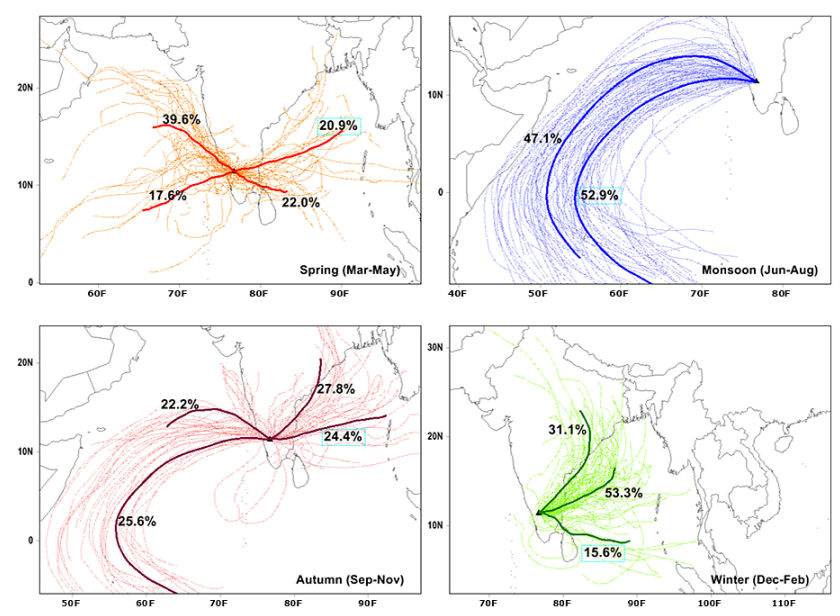

Figure 13. HYSPLIT isentropic back-trajectories for individual days and their cluster mean path during summer (spring), monsoon, autumn and winter seasons. The numbers represent the percentage of trajectories in each cluster.

\subsection{Role of long-range transport}

With a view to understand the influence of synoptic wind in determining the aerosol absorption characteristics at Ooty, we have examined the 5-day isentropic HYSPLIT backtrajectory (National Oceanic and Atmospheric Administration, NOAA) analysis, ending at $500 \mathrm{~m}$ a.g.l. Figure 13 shows the trajectory clusters along with the trajectories for individual days in each season of summer (spring), monsoon, autumn and winter. Consistent with the local meteorological data, the synoptic wind also showed distinct advection pathways with dominant easterly contribution during all seasons, 
Table 1. Annual BC mass concentration measured at different locations in India.

\begin{tabular}{|c|c|c|c|c|}
\hline Location & Type of location & Altitude (m) & Mean BC $\left(\mu \mathrm{g} \mathrm{m}^{3}\right)$ & Reference \\
\hline \multicolumn{5}{|l|}{ High-altitude stations in India } \\
\hline Nainital $\left(29.40^{\circ} \mathrm{N} 79.5^{\circ} \mathrm{E}\right)$ & & 1958 & 1.36 & Pant et al. (2006) \\
\hline NCO-P, Nepal $\left(27.95^{\circ} \mathrm{N} 86.82^{\circ} \mathrm{E}\right)$ & & 5079 & 0.91 & Marinoni et al. (2010) \\
\hline Singhad $\left(18.36^{\circ} \mathrm{N} 73.75^{\circ} \mathrm{E}\right)$ & & 1450 & 0.86 & Raju et al. (2011) \\
\hline Darjeeling $\left(27.04^{\circ} \mathrm{N} 88.26^{\circ} \mathrm{E}\right)$ & & 2050 & 5.60 & Chatterjee et al. (2010) \\
\hline Dehradun $\left(30.34^{\circ} \mathrm{N} 78.04^{\circ} \mathrm{E}\right)$ & & 700 & 4.40 & Kant and Dadhwal (2010) \\
\hline Kullu $\left(31.96^{\circ} \mathrm{N} 77.11^{\circ} \mathrm{E}\right)$ & & 1220 & 4.60 & Raju et al. (2011) \\
\hline Shillong $\left(25.57^{\circ} \mathrm{N} 91.88^{\circ} \mathrm{E}\right)$ & & 1965 & 5.00 & Kundu and Borgohain (2010) \\
\hline Hanle $\left(32.78^{\circ} \mathrm{N} 78.95^{\circ} \mathrm{E}\right)$ & & 4520 & 0.07 & Babu et al. (2011a) \\
\hline Ooty $\left(11.23^{\circ} \mathrm{N} 76.43^{\circ} \mathrm{E}\right)$ & & 2520 & 0.61 & Present Study \\
\hline \multicolumn{5}{|l|}{ Other stations in India } \\
\hline Anantpur $\left(14.62^{\circ} \mathrm{N}, 77.65^{\circ} \mathrm{E}\right)$ & Semi-arid, Rural & 331 & 3.03 & Suresh Kumar et al. (2012) \\
\hline Delhi $\left(28.58^{\circ} \mathrm{N} 77.2^{\circ} \mathrm{E}\right)$ & Urban, Industrialized & 260 & $3-27$ & Beegum et al. (2009) \\
\hline Pune $\left(18.54^{\circ} \mathrm{N} 73.85^{\circ} \mathrm{E}\right)$ & Urban, Industrialized & 457 & 4.1 & Safai et al. (2007) \\
\hline Ahmedabad $\left(23.5^{\circ} \mathrm{N} 72.60^{\circ} \mathrm{E}\right)$ & Urban, Industrialized & 55 & $0.21-10.2$ & Ramachandran and Rajesh (2007) \\
\hline Hyderabad $\left(17.48^{\circ} \mathrm{N} 78.40^{\circ} \mathrm{E}\right)$ & Urban & 557 & $1.5-11.2$ & Latha et al. (2004) \\
\hline Bangalore $\left(12.97^{\circ} \mathrm{N} 77.59^{\circ} \mathrm{E}\right)$ & Urban, Continental & 960 & 4.2 & Babu et al. (2002) \\
\hline Kanpur $\left(26.47^{\circ} \mathrm{N} 80.33^{\circ} \mathrm{E}\right)$ & Urban, Continental & 142 & 6-20 & Tripathi et al. (2005) \\
\hline Trivandrum $\left(8.55^{\circ} \mathrm{N} 76.94^{\circ} \mathrm{E}\right)$ & Costal, Urban & 10 & $0.5-8.0$ & Babu and Moorthy (2002) \\
\hline Udaipur $\left(24.58^{\circ} \mathrm{N} 73.68^{\circ} \mathrm{E}\right)$ & Semi-arid & 600 & 5.6 & Vyas $(2010)$ \\
\hline Bhubaneswar $\left(20.26^{\circ} \mathrm{N} 85.83^{\circ} \mathrm{E}\right)$ & Urban & 45 & 5.2 & Das (2009) \\
\hline
\end{tabular}

except in monsoon, where northwesterly marine air mass prevailed. Thus it appears that the potential sources were mainly distributed to the eastern locations of Ooty, i.e. anthropogenically polluted metropolitan cities like Chennai and Bangalore, which mostly modulated the seasonal variation of $\mathrm{BC}$ in summer, monsoon and autumn, while the sole marine air mass contribution during monsoon led to the lowest values of BC. Adding to the synoptic source effect, the local thermodynamics in summer support the enhanced concentration of $\mathrm{BC}$ at the high-altitude site, leading to the highest concentration at this season.

\subsection{Discussion}

In Tables 1 and 2, we have compared the observed annual (Table 1) and seasonal (Table 2) mean values of BC at Ooty with those observed at other locations, representative of distinct geographic environments, such as high-altitude, urban, coastal and continental locations.

The annual variation of $\mathrm{BC}$ mass concentration at Ooty resembles to those reported for other high-altitude locations. Over the high-altitude Himalayan aerosol observatory at Hanle, Babu et al. (2011b) also reported spring (March-May) high values of BC mass concentrations. Marinoni et al. (2010) also reported maximum BC concentrations $\left(\sim 340 \mathrm{ng} \mathrm{m}^{-3}\right)$ at another high-altitude Himalayan site (Nepal Climate Observatory Pyramid) during the premonsoon period (April). The seasonal variation of BC concentration at Manora Peak, Nainital also showed maximum values during March to April (Hema et al., 2010-2011). The present study of higher BC loading in summer (MarchMay) resembles well other high-altitude locations, followed by winter and minimum in the monsoon.

Lee and Kim (2010) reported that over the Southeast Asian region, $\mathrm{BC}$ from local emissions accumulates during the boreal spring (March-May). Associated with anthropogenic sources (biomass and fossil fuel burning), the concentration increases at times when local generation of aerosol is prominent. The changes in emission sources and variability in meteorological conditions also play a major role. While the shallower mixed-layer depth and low ventilation coefficient cause higher $\mathrm{BC}$ in winter over low-altitude regions, the stronger vertical mixing of aerosol during summer plays a dominant role in the seasonal high concentration of $\mathrm{BC}$ at high-altitude locations. On the other hand, a higher rain rate results in a higher aerosol deposition rate of aerosol within a precipitating cloud, while during meagre rainfall, a steady increase in average $\mathrm{BC}$ level coupled with continued generation and longer lifetime is expected during dry months over the low-altitude locations. It is seen for our meteorological features in Fig. 2 that $80 \%$ of rainfall occurs during the monsoon season, leading to strong wet removal of aerosols. In comparison to the dry deposition, heavy rainfall resulted in considerably decreased BC concentration, as rainfall is the effective scavenger of atmospheric aerosol. 
Table 2. Seasonal variation of BC concentration measured at different locations in India.

\begin{tabular}{|c|c|c|c|c|c|c|c|}
\hline \multirow[b]{2}{*}{ Location } & \multirow{2}{*}{$\begin{array}{l}\text { Type of } \\
\text { location }\end{array}$} & \multirow[b]{2}{*}{ Measurement method } & \multicolumn{4}{|c|}{$\mathrm{BC}$ mass concentration $\left(\mathrm{ng} \mathrm{m}^{-3}\right)$} & \multirow[b]{2}{*}{ References } \\
\hline & & & Summer & Monsoon & Autumn & Winter & \\
\hline Bangalore $\left(12.97^{\circ} \mathrm{N} 77.59^{\circ} \mathrm{E}\right)$ & $\begin{array}{l}\text { Urban, } \\
\text { Continental }\end{array}$ & $\begin{array}{l}\text { Aethalometer - Magee } \\
\text { Scientific GRIMM optical } \\
\text { mass spectrometer }\end{array}$ & 4025 & 1885 & 3485 & 3430 & Satheesh et al. (2011) \\
\hline Hyderabad $\left(17.48^{\circ} \mathrm{N} 78.40^{\circ} \mathrm{E}\right)$ & Urban & & 787 & 2584 & 3605 & 6805 & Babu et al. (2011b) \\
\hline Pune $\left(18.54^{\circ} \mathrm{N} 73.85^{\circ} \mathrm{E}\right)$ & $\begin{array}{l}\text { Urban, } \\
\text { Industrialized }\end{array}$ & $\begin{array}{l}\text { Aethalometer (Magee } \\
\text { Scientific AE-42) }\end{array}$ & 3250 & 1310 & 6040 & 7380 & Safai et al. (2007) \\
\hline Delhi $\left(28.58^{\circ} \mathrm{N} 77.2^{\circ} \mathrm{E}\right)$ & $\begin{array}{l}\text { Urban, } \\
\text { Industrialized }\end{array}$ & & 12470 & 24870 & 22000 & 12400 & Rai et al. (2002) \\
\hline Ahmedabad $\left(23.5^{\circ} \mathrm{N} 72.60^{\circ} \mathrm{E}\right)$ & $\begin{array}{l}\text { Urban, } \\
\text { Industrialized }\end{array}$ & & 2200 & 1500 & 7300 & 5500 & Ganguly and Jayaraman (2006) \\
\hline Trivandrum $\left(8.55^{\circ} \mathrm{N} 76.94^{\circ} \mathrm{E}\right)$ & $\begin{array}{l}\text { Coastal, } \\
\text { Urban }\end{array}$ & & 2620 & 2010 & 3460 & 5680 & Krishna Moorthy et al. (2007) \\
\hline NCOP Nepal $\left(27.95^{\circ} \mathrm{N} 86.82^{\circ} \mathrm{E}\right)$ & $\begin{array}{l}\text { High } \\
\text { altitude }\end{array}$ & $\begin{array}{l}\text { Multi-angle absorption } \\
\text { photometer (MAPP-5012 } \\
\text { Thermo Electron } \\
\text { Corporation) }\end{array}$ & 320 & 56 & 137 & 125 & Marinoni et al. (2010) \\
\hline Hanle $\left(32.78^{\circ} \mathrm{N} 78.95^{\circ} \mathrm{E}\right)$ & $\begin{array}{l}\text { High } \\
\text { altitude }\end{array}$ & $\begin{array}{l}\text { Two-channel aethalometer - } \\
\text { (Magee Scientific AE-31) }\end{array}$ & 110 & 63 & 72 & 68 & Babu et al. (2011a) \\
\hline Nainital $\left(29.40^{\circ} \mathrm{N} 79.5^{\circ} \mathrm{E}\right)$ & $\begin{array}{l}\text { High } \\
\text { altitude }\end{array}$ & $\begin{array}{l}\text { Seven-channel aethalometer } \\
\text { (Magee Scientific AE-31), }\end{array}$ & 1340 & 530 & 1030 & 1100 & Dumka et al. (2010) \\
\hline Dehradun $\left(30.34^{\circ} \mathrm{N} 78.04^{\circ} \mathrm{E}\right)$ & $\begin{array}{l}\text { High } \\
\text { altitude }\end{array}$ & & 4233 & 2675 & 3041 & 6737 & Babu et al. (2011b) \\
\hline Ooty $\left(11.23^{\circ} \mathrm{N} 76.43^{\circ} \mathrm{E}\right)$ & $\begin{array}{l}\text { High } \\
\text { altitude }\end{array}$ & $\begin{array}{l}\text { Seven-channel aethalometer } \\
\text { (Magee Scientific AE-31), }\end{array}$ & 960 & 230 & 350 & 770 & Present study \\
\hline
\end{tabular}

\section{Conclusions}

The continuous measurement of aerosol $\mathrm{BC}$ concentrations over the South Indian high-altitude location Ooty for a period of 2 years reveals the distinct nature of the prevalence of absorbing aerosols and their seasonality. On the shorter timescale, the $\mathrm{BC}$ concentrations showed prominent diurnal variations during summer (February-May), which were subdued during the other seasons. Seasonally, BC depicted highest mass concentrations $\left(M_{\mathrm{BC}}\right)$ during summer $\left(M_{\mathrm{B}}=0.96 \pm 0.35 \mu \mathrm{g} \mathrm{m}^{-3}\right)$ and lowest in monsoon $\left(M_{\mathrm{B}}=\right.$ $0.23 \pm 0.06 \mu \mathrm{g} \mathrm{m}^{-3}$ ). The higher BC abundance during summer is attributed to the increased turbulence and vertical mixing of $\mathrm{BC}$ due to extended duration of daytime and abundant availability of solar radiation. In addition, the long-range transported aerosols (dominant easterly advection) also contributed to the higher $\mathrm{BC}$ concentration in summer.

Examination of the spectral variation of absorption coefficients at different seasons indicates mainly the dominance of fossil fuel combustion aerosols with highest seasonal mean value of $\alpha_{\text {abs }}(\sim 1.24 \pm 0.14)$ in summer and lowest $\alpha_{\text {abs }}$ $(\sim 0.86 \pm 0.19)$ in monsoon. The moderately higher value of $\alpha_{\mathrm{abs}}$ in summer thus indicated the presence of biomass burning aerosols too, being influenced by the synoptic winds from the fire infected regions around the experimental site.

The study of the variation of $\mathrm{BC}$ with the local meteorological parameters showed better association of the concentration of $\mathrm{BC}$ with temperatures during the summer season. The $\mathrm{BC}$ concentrations also showed better correlation with wind speed in summer, thus indicating an increase in the ventilation coefficients, which led to the highest $\mathrm{BC}$ concentration in summer. The wind of continental origin was found to have significant contribution to higher BC concentration in summer.

The higher $\mathrm{BC}$ concentration at higher altitudes during summer (or spring) season has great significance on regional and global climate. It can act as a heat pump over the northern Indian and Himalayan foothill locations and modulate the Indian summer monsoon. Our observation is also in line with earlier observations of the existence of aerosol layers extending from the Indian Ocean to the Himalayan region having a vertical extent of $\sim 3 \mathrm{~km}$ (Babu et al., 2011a).

Acknowledgements. This work was carried out as part of the AFRI project of ISRO-GBP. The authors are grateful to K. Krishna Moorthy, Director (SPL) for his help and constant encouragement. We also acknowledge NOAA Air Resources Laboratory for the provision of the HYSPLIT transport and dispersion model and the READY website (http://www.arl.noaa.gov/ready.html) used in this publication.

Topical Editor P. M. Ruti thanks two anonymous referees for their help in evaluating this paper. 


\section{References}

Arnott, W. P., Hamasha, K., Moosmüller, H., Sheridan, P. J., and Ogren, A. J.: Towards aerosol light-absorption measurements with a 7-wavelength aethalometer: evaluationwith a photoacoustic instrument and 3-wavelength nephelometer, Aerosol Sci. Technol., 39, 17-29, 2005.

Babu, S. S. and Moorthy, K. K.: Aerosol Black Carbon over a Tropical Station in India, Geophys. Res. Lett., 29, 2098, doi:10.1029/2002GL015662, 2002.

Babu, S. S., Satheesh, S. K., and Moorthy, K. K.: Aerosol Radiative Forcing Due to Enhanced Black Carbon at an Urban Site in India, Geophys. Res. Lett., 29, 1880, doi:10.1029/2002GL015826, 2002.

Babu, S. S., Chaubey, J. P., Moorthy, K. K., Gogoi, M. M., Kompalli, S. K., Sreekanth, V., Bagare, S. P., Bhatt, B. C., Gaur, V. K., Prabhu, T. P., and Singh, N. S.: High altitude $(\sim 4520 \mathrm{~m}$ amsl $)$ measurements of black carbon aerosols over western transHimalayas: Seasonal heterogeneity and source apportionment, J. Geophys. Res., 116, D24201, doi:10.1029/2011JD016722, 2011a.

Babu, S. S., Moorthy, K. K., Manchanda, R. K., Sinha, P. R., Satheesh, S. K., Vajja, D. P., Srinivasan, S., and Kumar, V. H. A.: Free trophospheric black carbon aerosol measurements using high altitude balloon: Do BC layers build their own homes up in the atmosphere?, Geophys. Res. Lett., 38, L08803, doi:10.1029/2011GL046654, 2011b.

Balakrishnaiah, G., Kumar, K. R., Reddy, B. S. K., Gopal, K. R., Reddy, R. R., Reddy, L. S. S., Ahammed, Y. N., Narasimhulu, K., Moorthy, K. K., and Babu, S. S.: Analysis of Optical Properties of Atmospheric Aerosols Inferred from Spectral AODs and Ångström Wavelength Exponent, J. Atmos. Environ., 45, 12751285, 2011.

Beegum, N. S., Krishnamoorthy, K., Suresh Babu, S., Satheesh, S. K., Vinoj, V., Badarinath, K. V. S., Safai, P. D., Devara, P. C. S., Sacchidanand Singh, Vinod, Dumka, U. C., and Pant, P.: Spatial distribution of aerosol black carbon over India during premonsoon season, J. Atmos. Environ, 43, 1071-1078, 2009.

Bergstrom, R. W., Pilewskie, P., Russell, P. B., Redemann, J., Bond, T. C., Quinn, P. K., and Sierau, B.: Spectral absorption properties of atmospheric aerosols, Atmos. Chem. Phys., 7, 5937-5943, doi:10.5194/acp-7-5937-2007, 2007.

Cao, J. J., Zhu, C. S., Chow, J. C., Watson, J. G., Han, Y. M., Wang, G. H., Shen, Z. X., and An, Z. S.: Black Carbon Relationships with Emission and Meteorology in Xi' an, China, Atmos. Res., 94, 194-202, 2009.

Chatterjee, A., Adak A., Ghosh, S. K., Raha, S., Singh A. K., and Yadav, Y.: Atmospheric black carbon removal with efficient rainfall scavenging over Darjelling during wouthwest monsoon, Aerosol and clouds: Climate change prospective, IAST Conference 19, 442-443, 2010.

Corrigan, C. E., Ramanathan, V., and Schauer, J. J.: Impact of monsoon transitions on the physical and optical properties of aerosols, J. Geophys. Res., 111, D18208, doi:10.1029/2005JD006370, 2006.

Das, N., Baral, S. S., Sahoo, S. K., Mohapatra, R. K., Ramulu, T. S., Das, S. N., and Chaudhury, G. R.: Aerosol physical characteristics at Bhubaneswar, East coast of India, J. Atmos. Res., 93, 897-901, 2009.
Dumka, U. C., Moorthy, K. K, Kumar, R., Hegde, P., Sagar, R., Pant, P., Singh, N., and Babu, S. S.: Characteristics of Aerosol Black Carbon Mass Concentration over a High Altitude Location in the Central Himalayas from Multi-year Measurements, Atmos. Res., 96, 510-521, 2010.

Gabriel, R., Mayol-Bracero, O. L., and Andreae, M. O.: Chemical characterization of submicron aerosol particles collected over the Indian Ocean, J. Geophys. Res., 107, INDX2-4.1-INDX2-4.12, doi:10.1029/2000JD000034, 2002.

Ganguly, D. and Jayaraman, A.: Physical and optical properties of aerosols over an urban location in western India: Implications for shortwave radiative forcing, J. Geophys. Res., 111, D24207, doi:10.1029/2006JD007393, 2006.

Gogoi, M. M., Krishna Moorthy, K., Sobhankumar, K., Jai Prakash, C., Suresh Babu, S., Manoj, M. R., Vijayakumar, S. N., and Tushar, P.: Physical and optical properties of aerosols in a free tropospheric environment: Results from long term observations over western trans - himalayas, J. Atmos. Environ., 84, 262-274, 2014.

Hansen, D. A., Rosen, H., and Novakov, T.: The Aethalometer - An instrument for the real-time measurement of optical absorption by aerosol particles, Sci. Total Environ., 36, 191-196, 1984.

Haywood, J. M. and Shine, K. P.: Multi-spectral Calculations of the Radiative Forcing of Tropospheric Sulphate and Soot Aerosols Using a Column Model, Q. J. Roy. Meteorol. Soc., 123, 19071930, 1997.

Hema, J., Pant, P., Chandoal, H. C., Kumar, R., Dumuka, U. C, Naja, M., and Mungali, M.: Intensification of Research in High Priority Areas (IRHPA), Annual Report, 2010-2011.

IPCC (Intergovernmental Panel on Climate Change): The Scientific Basis, in: Contribution of Working Group I to the Fourth Assessment Report of the Intergovernmental Panel on Climate Change, edited by: Solomon, S., Qin, D., Manning, M., Chen, Z., Marquir, M., Averyt, K. B., Tignor, M., and Miller, H. L., Cambridge Univ. Press, New York, Climate Change, 2007.

Jacobson, M. Z.: Strong radiative heating due to the mixing state of black carbon in atmospheric aerosols, Nature, 409, 695-697, 2001.

Jacobson, M. Z.: Control of fossil-fuel particulate black carbon and organic matter, possibly the most effective method of slowing global warming, J. Geophys. Res. Atmos., 107, 4401, doi:10.1029/2001JD001376, 2002.

Janssen, N. A., Gerlofs-Nijland, M. E., Lanki, T., Salonen, R. O., Flemming, C., Hoek, G., Fischer, P., Brunekreef, B., and Krzyzanowski, M.: Health effects of black carbon, WHO Regional Office for Europe, Scherfigsvej 8, DK-2100 Copenhagen Ø, Denmark, 2012.

Kant, Y. and Dadhwal, V. K.: Diurnal and seasonal variation of Black carbon and aerosols over Dehradun, Aerosol and clouds: Climate change prospective, IAST Conference, 19, 461-462, 2010.

Kirchstetter, T. W., Novakov, T., and Hobbs, P. V.: Evidence that the spectral dependence of light absorption by aerosols is affected by organic carbon, J. Geophys. Res., 109, D21208, doi:10.1029/2004JD004999, 2004.

Krishna Moorthy, K., Suresh Babu, S., and Satheesh, S. K.: Temporal heterogeneity in aerosol characteristics and the resulting radiative impact at a tropical coastal station - Part 1: Micro- 
physical and optical properties, Ann. Geophys., 25, 2293-2308, doi:10.5194/angeo-25-2293-2007, 2007.

Kundu, S. S. and Borgohain, A.: BC mass concentration and AOD characteristics over Meghalaya, Shillong, ARFI \& ICARB Scientific Progress Report ISRO-GBP, India, 81-83, 2010.

Latha, K. M., Badarinath, K. V. S., and Moorthy, K. K.: Impacts of Diesel Vehicular Emissions on Ambient BC Concentration at an Urban Location in India, Curr. Sci., 86, 451-453, 2004.

Lee, W. and Kim, M.: Effects of Radiative forcing by black carbon aerosols on spring rainfall decrease over Southeast Asia, Atmos. Environ., 44, 3739-3744, 2010.

Marinoni, A., Cristofanelli, P., Laj, P., Duchi, R., Calzolari, F., Decesari, S., Sellegri, K., Vuillermoz, E., Verza, G. P., Villani, P., and Bonasoni, P.: Aerosol mass and black carbon concentrations, a two year record at NCO-P (5079 m, Southern Himalayas), Atmos. Chem. Phys., 10, 8551-8562, doi:10.5194/acp-10-85512010, 2010.

Moorthy, K. K., Pillai, P. S., and Babu, S. S.: Influence of Changes in the Prevailing Synoptic Conditions on the Response of Aerosol Characteristics to Land/sea Breeze Circulations at a Coastal Station, Bound.-Lay. Meteorol., 108, 145-161, 2003.

Moorthy, K. K., Babu, S. S., Sunilkumar, S. V., Gupta, P. K., and Gera, B. S.: Altitude profiles of aerosol BC, derived from aircraft measurements over an inland urban location in India, Geophys. Res. Lett., 31, L22103, doi:10.1029/2004GL021336, 2004.

Moorthy, K. K., Satheesh, S. K., Babu, S. S., and Dutt, C. B. S.: Integrated campaign for Aerosols, Gases and Radiation budget (ICARB): An overview, J. Earth Syst. Sci., 117, 243-262, 2008.

Myhre, G., Stordal, F., Restad, K., and Isaksen, I. S. A.: Estimation of the Direct Radiative Forcing Due to Sulfate and Soot Aerosols, Tellus, 50, 463-477, 1998.

Nair, V. S., Moorthy, K. K., Alappattu, D. P., Kunhikrishnan, P. K., George, S., Nair, P. R., Babu, S. S., Abish, B., Satheesh, S. K., Tripathi, S. N., Niranjan, K., Madhavan, B. L. Srikant, V., Dutt, C. B. S., Badarinath, K. V. S., and Reddy, R. R.: Wintertime Aerosol Characteristics over the Indo-Gangetic Plain (IGP): Impacts of the Local Boundary Layer Processes and Long-range Transport, J. Geophy. Res., 112, D13205, doi:10.1029/2006JD008099, 2007.

Nair, V. S., Suresh Babu, S., and Krishna Moorthy, K.: Spatial distribution and spectral characteristics of aerosol single scattering albedo over the Bay of Bengal inferred from ship borne measurements, Geophys. Res. Lett., 35, L10806, doi:10.1029/200891033687, 2008

Novakov, T., Ramanathan, V., Hansen, J. E., Kirchstetter, T. W., Sato, M., Sinton, J. E., and Sathaye, J. A.: Large historical changes of fossil-fuel black carbon aerosols, Geophys. Res. Lett., 2003 .
Oshima, N., Kondo, Y., Moteki, N., Takegawa, N., Koike, M., Kita, K., Matsui, H., Kajino, M., Nakamura, H., Jung, J. S., and Kim, Y. J.: Wet removal of black carbon in Asian outflow: Aerosol Radiative Forcing in East Asia (A-FORCE) aircraft campaign, J. Geophys. Res., 117, D03204, doi:10.1029/2011JD016552, 2012.

Pant, P., Hegde, P., Dumka, U. C., Sagar, R., Satheesh, S. K., Moorthy, K. K., Saha, A., and Srivastava, M. K.: Aerosol Characteristics at a High Altitude Location in Central Himalayas: Optical Properties and Radiative Forcing, J. Geophys. Res., 111, D17206, doi:10.1029/2005JD006768, 2006.

Rai, K., Sarkar, A. K., and Mitra, A. P.: Chemical characterization of aerosols at NPL, Delhi, IASTA Bull. Spec. 1ssue, 14, 155-158, 2002.

Raju, M. P., Safai, P. D., Rao, P. S. P., Devara, P. C. S., and Budhavant, K. B.: Seasonal Characteristics of Black Carbon Aerosols over a High Altitude Station in Southwest India, Atmos. Res., 100, 103-110, 2011.

Ramachandran, S. and Rajesh, T. A.: Black Carbon Aerosol Mass Concentration over Ahmedabad, an Urban Location in Western India: Comparison with Urban Sites in Asia, Europe, Canada, and the United States, J. Geophys. Res., 112, D06211, doi:10.1029/2006JD007488, 2007.

Safai, P. D., Kewat, S., Praveen, P. S., Rao, P. S. P., Momin, G. A., Ali, K., and Devara, P. C. S.: Seasonal Variation of Black Carbon Aerosols over Tropical Urban City of Pune, India. Atmos. Environ, 41, 2699-2709, 2007.

Satheesh, S. K., Vinoj, V., and Moorthy, K. K.: Weekly periodicities of aerosol properties observed at an urban location in India, Atmos. Res, 101, 307-313, 2011.

Suresh Kumar, R., Raghavendra Kumar, K., Balakrishnaiah, G., Rama Gopal, K., Reddy, R. R., Reddy, L. S. S., Nazeer Ahammed, Y., Narasimhulu, K., Krishna Moorthy, K., and Suresh Babu, S.: Potential Source Regions Contributing to Seasonal Variations of Black Carbon Aerosols over Anantapur in Southeast India, Aerosol Air Qual. Res., 12, 344-358, 2012.

Tripathi, S. N., Dey, S., Tare, V., and Satheesh, S. K.: Aerosol Black Carbon Radiative Forcing at an Industrial City in Northern India, Geophys. Res. Lett., 32, L08802, doi:10.1029/2005GL022515, 2005.

Vyas, B. M.: Studies of regional features of atmospheric aerosol, total carbonaceous aerosols and their role in the atmospheric radiative forcing effect over the tropical semi-arid location i.e. Udaipur, western region part of India, ARFI \& ICARB Scientific Progress Report ISRO-GBP, India, 67-70, 2010.

Weingartner, E., Saathoff, H., Schnaiter, M., Strit, N., Bitnar, B., and Baltensperger, U.: Absorption of Light by Soot Particles: Determination of the Absorption Coefficient by Means of Aethalometer, J. Aerosol. Sci., 34, 1445-1463, 2003. 